Arkadiusz Niewiadomski

Katedra Geografii Fizycznej, Pracownia Gleboznawstwa i Geoekologii Wydział Nauk Geograficznych, Uniwersytet Łódzki

Artykuł wpłynął do redakcji 18.11.2013; po recenzjach zaakceptowany 12.12.2013

\title{
STRUKTURA I ZNACZENIE TERENÓW ZIELENI W LODZI NA TLE DUŻYCH OŚRODKÓW MIEJSKICH W POLSCE
}

\section{THE STRUCTURE AND IMPORTANCE OF GREEN AREAS IN LÓDŹ IN COMPARISON WITH OTHER BIG CITIES IN POLAND}

Artykuł dotyczy określenia roli w strukturze miasta oraz wszechstronnego znaczenia terenów zieleni w podziale na podstawowe kategorie. W pracy wskazano mnogość funkcji niektórych obiektów oraz skalę ich oddziaływania w przestrzeni. Główną część stanowi analiza porównawcza udziału powierzchni zajmowanej przez poszczególne rodzaje terenów zieleni w ogólnej powierzchni wybranych dużych miast w Polsce z uwzględnieniem zmian jakie zaszły w okresie ostatnich kilkunastu lat. Zwrócono także uwagę na problemy związane $\mathrm{z}$ pielęgnacją i dostępnością terenów zieleni. Wyniki analizy wykazały, iż Łódź jest jednym z najbardziej „zielonych” miast w Polsce, a niektóre kategorie terenów zieleni odgrywają szczególną rolę w ekologii miasta i gospodarce przestrzennej.

Słowa kluczowe: zieleń miejska, Łódź, zagospodarowanie przestrzenne, krajobraz miejski

\section{WPROWADZENIE}

Problematyka terenów zieleni jest jednym z ciekawszych zagadnień wielu dziedzin wiedzy i gospodarki zajmujących się obszarami miejskimi. $\mathrm{Z}$ uwagi na liczne funkcje oraz wieloaspektowe znaczenie, tereny zieleni, zwłaszcza w dużych miastach, podlegały znacznym przekształceniom (Czerwieniec, Lewińska 2000; Przesmycka 2005). Zmiany zachodzące w ujęciu historycznym warunkujące rozwój poszczególnych ośrodków, jak i ewolucja przestrzeni miejskiej z punktu widzenia gospodarki przestrzennej oraz architektury 
i fizjonomii krajobrazu, odciskają stałe piętno na terenach zieleni miejskiej (Słodczyk 2001; Bazan-Krzywoszańska 2005; Przesmycka 2005; Pancewicz 2007). Powoduje to ograniczanie jednych form i powstawanie nowych, a ponadto zmianę funkcji zachodzącą $\mathrm{w}$ obrębie tych samych obiektów. Dynamika ta jest interesująca $\mathrm{z}$ uwagi na kwestie społeczne, ekologiczne, a nawet gospodarcze. W tym względzie Łódź, jako duży ośrodek miejski, stanowi doskonały poligon badawczy. Strukturę miasta charakteryzuje duża różnorodność obiektów wchodzących w skład terenów zieleni, podobnie jak i mnogość funkcji. Zamysłem autora było określenie kierunków przemian tychże obszarów w przestrzeni miejskiej oraz wskazanie tendencji rozwoju poszczególnych form oraz funkcji przez nie pełnionych. Celem dodatkowym było porównanie terenów zieleni Łodzi do analogicznych obszarów w innych dużych ośrodkach miejskich w Polsce, zarówno pod względem ilościowym, jak i jakościowym.

\section{MATERIAL I METODY}

Badania prowadzono na obszarze miasta Łodzi w latach 2011-2012 w ramach dotacji celowej na rozwój badań dla młodych naukowców. Przeprowadzono inwentaryzację terenów zieleni, z wyróżnieniem ich kategorii w przestrzeni miejskiej (sumarycznie) oraz osiedlowej i lokalnej wraz z próbą określenia funkcji na bazie sposobów wykorzystania, bądź roli danego obiektu w przestrzeni geograficznej miasta.

Analizy matematyczno-statystyczne (wyliczenie średnich, obliczenie powierzchni przypadającej na jednego mieszkańca, określenie procentowego udziału wybranych kategorii terenów zieleni) przeprowadzono w oparciu o dane pozyskane z Banku Danych Lokalnych (BDL) dostępnego na stronie internetowej Głównego Urzędu Statystycznego. Zbiór danych uzupełniono o dane pozyskane z literatury dotyczącej terenów zieleni Łodzi oraz innych dużych ośrodków miejskich. Wybór miast ograniczono do największych pod względem liczby ludności jednostek w poszczególnych województwach (miasta wojewódzkie oraz największe ośrodki miejskie w regionie).

\section{WYNIKI BADAŃ I DYSKUSJA}

Do przełomu XVIII i XIX wieku terytorium dzisiejszej Łodzi było obszarem wykazującym wysoki współczynnik lesistości. A. Matczak (1994) podaje, iż około $3 / 4$ powierzchni dzisiejszej Łodzi stanowiły lasy. W XIX wieku w przestrzeni miasta rozwijały się głównie tereny parków, co miało miejsce w większości dużych ośrodków miejskich w Polsce. Okres wojen światowych i międzywojnia charakteryzowała stagnacja $w$ zakresie ewolucji i rozwoju 
terenów zieleni wynikające z konieczności zaspokojenia podstawowych potrzeb ludności miast. Brak nowych kategorii terenów zieleni oraz spadek znaczenia już istniejących obiektów z uwagi na ograniczenie zabiegów pielęgnacyjnych. W latach 1950-90 powierzchnia terenów zieleni miejskiej zwiększyła się trzykrotnie, z ok. 2 tys. ha do 5,7 tys. ha (Matczak 1994). W tym czasie w strukturze miast całej Polski intensywnie rozwijały się tereny osiedlowe i współtowarzyszące im tereny zieleni (skwery, ogrody działkowe, trawniki itp.). W Łodzi udział terenów zieleni osiedlowej we wspomnianym powyżej okresie wzrósł szesnastokrotnie, a udział ogrodów działkowych aż 27 razy.

Liczba i udział poszczególnych kategorii terenów zieleni w strukturze Łodzi podlegały od lat 90. niezbyt dynamicznym zmianom (tab. 1). Powierzchnia miasta nie podlegała znacznym zmianom. Jedynie na przełomie 2005 i 2006 roku Łódź zmniejszyła się o 114 ha (0,39\%) ogólnej powierzchni. Poza tym Łódź postrzegana jest jako ,zielone” miasto w porównaniu z innymi ośrodkami w Polsce, co wpływa ograniczająco na chęć tworzenia nowych obiektów i terenów zieleni. Tendencją obserwowaną w dużych miastach Polski jest ograniczanie powierzchni ogólnodostępnych obszarów zieleni, zarówno urządzonej, jak i nieurządzonej, stanowią one bowiem tereny inwestycyjne dla lokalizacji miejsc parkingowych i postojowych w centrach miast, intensywnej rozbudowy sieci dróg pieszych i rowerowych, nowych terenów komunikacyjnych, lokalizacji obiektów gospodarki mieszkaniowej na obrzeżach miast oraz rozwoju innych rodzajów działalności ludzkiej (Przesmycka 2005; Urbański $i$ in. 2009). Zmiany dają się zauważyć także pod względem jakościowym, co wynika przede wszystkim z niskiego stopnia pielęgnacji roślinności porastającej niektóre kategorie terenów zieleni (np. zieleni osiedlowej) oraz zanieczyszczenia powietrza i gleb, które wywołują negatywne zmiany w ekosystemach zieleni przyulicznej, lasów miejskich czy parków (Niedbała i in. 2010; Dusza-Dobek 2012; Szwalec, Mundała 2012). Zmniejszająca się liczba ludności w Łodzi powoduje pozorną korzystną zmianę jaką jest wzrost udziału sumarycznej powierzchni zieleni miejskiej przypadającą na jednego mieszkańca.

Zmiany struktury obszarów miejskich i związane $\mathrm{z}$ tym przemiany funkcjonalne mogą powodować wzrost zainteresowania terenami zielonymi w miastach. Ma to szczególne znaczenie w kształtowaniu miast przemysłowych celem łagodzenia agresywnego charakteru przestrzeni poprzez przywracanie równowagi kompozycyjnej i krajobrazowej (Pancewicz 2007). Mimo braku harmonii krajobrazu, sąsiedztwo skrajnie różnych form gospodarowania wpływa na zwiększenie atrakcyjności tych terenów. Można to opisać mianem znaczenia psychologicznego definiującego tereny zieleni jako odprężające i wyróżniające się fizjonomicznie w strukturze miejskiej od zwartej zabudowy (Sutkowska 2006). Poza wspomnianym, terenom zielonym w zależności od kategorii, rodzaju i formy przypisywane jest znaczenie: ozdobne, kompozycji urbanistycznej, rekreacyjne, edukacyjne, zdrowotne, izolacyjne. Szczególnie podkreślane są 
ponadto: znaczenie społeczne, naukowe i ekologiczne. A. Matczak (1994) podaje, iż tereny zielone w Łodzi mają znaczenie wypoczynkowo-rekreacyjne. W latach 90. XX w. w tej formie użytkowało je około 30\% ludności. Poza tym, główne znaczenie skupiało się w obrębie funkcji sanitarno-higienicznej (tłumienie hałasu, osłona domów, oczyszczania powietrza, kształtowanie klimatu lokalnego), która jest najczęściej wskazywaną w gradacji znaczenia terenów zielonych w miastach (Mowszowicz, red. 1962; Sutkowska 2006).

Tab. 1

Zmiany struktury terenów zieleni w Łodzi w latach 1996-2010

Structure changes of green areas in Łódź in the years 1996-2010

\begin{tabular}{|l|c|c|c|c|c|c|c|c|c|}
\hline \multirow{2}{*}{ Rok* } & \multicolumn{2}{|c|}{$\begin{array}{c}\text { Parki } \\
\text { spacerowo- } \\
\text {-wypoczynkowe }\end{array}$} & \multicolumn{2}{|c|}{ Zieleńce } & $\begin{array}{c}\text { Zieleńn } \\
\text { uliczna }\end{array}$ & $\begin{array}{c}\text { Tereny } \\
\text { zieleni } \\
\text { osiedlo- } \\
\text { wej }\end{array}$ & \multicolumn{2}{|c|}{ Cmentarze** } & Lasy \\
\cline { 2 - 12 } & liczba & $\begin{array}{c}\text { pow. } \\
\text { (ha) }\end{array}$ & liczba & $\begin{array}{c}\text { pow. } \\
\text { (ha) }\end{array}$ & $\begin{array}{c}\text { pow. } \\
\text { (ha) }\end{array}$ & $\begin{array}{c}\text { pow. } \\
\text { (ha) }\end{array}$ & liczba & $\begin{array}{c}\text { pow. } \\
\text { (ha) }\end{array}$ & $\begin{array}{c}\text { pow. } \\
\text { (ha) }\end{array}$ \\
\hline 1996 & 35 & 600,8 & 148 & 276,4 & - & 871,3 & - & - & - \\
\hline 1997 & 35 & 600,8 & 148 & 276,4 & - & 859,9 & - & - & - \\
\hline 1998 & 35 & 600,8 & 148 & 276,4 & 78,0 & 842,9 & - & - & 1465,3 \\
\hline 1999 & 35 & 600,8 & 148 & 276,4 & 78,0 & 834,8 & - & - & 1467,7 \\
\hline 2000 & 35 & 600,8 & 148 & 276,4 & 78,0 & 853,6 & - & - & 1480,8 \\
\hline 2001 & 36 & 608,0 & 148 & 276,4 & 78,0 & 862,8 & - & - & 1505,3 \\
\hline 2002 & 36 & 608,0 & 148 & 276,4 & 78,0 & 862,8 & - & - & 1506,2 \\
\hline 2003 & 36 & 608,0 & 148 & 276,4 & 78,0 & 905,6 & - & - & 1452,5 \\
\hline 2006 & 37 & 616,6 & 148 & 276,4 & 78,0 & 925,5 & 27 & 224,5 & 1460,2 \\
\hline 2007 & 40 & 702,5 & 148 & 276,4 & 78,0 & 972,1 & 27 & 224,5 & 1465,5 \\
\hline 2008 & 39 & 626,5 & 148 & 276,4 & 78,0 & 972,1 & 27 & 224,5 & 1464,7 \\
\hline 2009 & 39 & 626,5 & 148 & 276,4 & 78,0 & 1018,1 & 27 & 224,5 & 1465,5 \\
\hline 2010 & 41 & 581,6 & 148 & 276,4 & 78,0 & 1018,1 & 27 & 224,5 & 1465,7 \\
\hline
\end{tabular}

* - w Banku Danych Lokalnych brak danych dotyczących statystyki terenów zielonych w Polsce za lata 2004-2005.

** - w Banku Danych Lokalnych brak danych dotyczących ilości i powierzchni cmentarzy w miastach Polski dla lat 1996-2005.

Funkcja ochronna stanowi szczególny przykład znaczenia terenów zieleni na obszarach miejskich. W przypadku niektórych ośrodków może mieć, mimo ich niewielkiego udziału, znaczącą rangę, tak jest np. w przypadku Kielc (Świercz 2011). Zieleń w strukturze centrum miasta może wyznaczać granice (np. historyczne) lub też stanowić łącznik pomiędzy różnymi układami architektonicznymi. Różnorodność form terenów zieleni wymaga ich rozdzielenia celem dokładniejszej charakterystyki. 


\subsection{PARKI SPACEROWO-WYPOCZYNKOWE}

Parki są terenami zielonymi występującymi w strukturze wszystkich miast. Pod względem funkcji, parki użytkowane są głównie jako tereny wypoczynku (zwłaszcza weekendowego). Mają poza tym duże znaczenie krajobrazowe, wpływają na wrażliwość estetyczną i emocjonalną. Ponadto spełniają także funkcje dydaktyczno-wychowawcze (zwłaszcza palmiarnie, ogrody zoologiczne i botaniczne wliczane często w obszary parków), jak ma to miejsce w Warszawie, Krakowie, Łodzi, Poznaniu, Gdańsku i innych miastach. Wśród funkcji wyższego rzędu podkreślić należy ułatwianie nawiązywania kontaktów społecznych (wspólne spacery, korzystanie z infrastruktury, imprezy masowe itp.). Ponadto bardzo ważnym jest znaczenie krajobrazowe i zdrowotne, które przyrównuje parki do terenów leśnych $\mathrm{z}$ uwagi na funkcję zdrowotną związaną z oczyszczaniem powietrza atmosferycznego, liczne walory estetyczne, poprawę harmonii krajobrazu poprzez nadanie bardziej naturalnego, przyrodniczego wymiaru. Właściwa pielęgnacja obiektów wpływa także na kwestię atrakcyjności poszczególnych części miasta choćby pod względem preferencji mieszkaniowych. Pierwsze założenia parkowe w Łodzi pochodzą z 1840 r., a do końca XIX wieku ich liczba sięgnęła kilkunastu (Mowszowicz, red. 1962). Duża ich liczba powstała już w latach 40. i 50. XX wieku. Ważną cechą łódzkich parków było i jest duże bogactwo florystyczne, wpływające na ich znaczenie dydaktyczne oraz ekologiczne.

Istotną kwestią określającą znaczenie parków w strukturze terenów zieleni jest zasięg ich oddziaływania. Badania takie przeprowadzone były w Łodzi przez A. Matczaka (1995). Autor wykazał, iż większość parków ma znaczenie jedynie lokalne (dzielnicowe, osiedlowe). Słaby stopień zagospodarowania i ograniczona pielęgnacja polegająca na usuwaniu dużej ilości drzew, przekraczającej wielkość nasadzeń (Urbański i in. 2009) wpływają na zmniejszenie ich atrakcyjności. Tylko obiekty skupiające różnorodne funkcje (zwłaszcza posiadające zbiorniki wodne wykorzystywane jako kąpieliska) i posiadające dużą ilość infrastruktury mają zasięg ogólnomiejski, a czasami nawet szerszy.

Udział parków w strukturze terenów zieleni w Łodzi jest zbliżony do średniej wartości w Polsce (tab. 2). Trzykrotnie wyższy udział posiadają Bydgoszcz i Katowice, a zdecydowanie niższy w Białymstoku, Toruniu i Kielcach (ponad dwa razy mniejszy udział niż w Łodzi).

Łódzkie parki obecnie podlegają intensywnej rewitalizacji, czego dowodem są realizowane na ich obszarach projekty rewitalizacji. Wzmożona pielęgnacja powoduje wzrost znaczenia ekologicznego parków, stanowiących ,zielone enklawy" w przestrzeni zwartej zabudowy osiedlowej i śródmiejskiej. Wzrasta także ich znaczenie społeczne jako terenów wypoczynku, głównie z uwagi na rozbudowę infrastruktury rekreacyjnej, czego przykładem są m.in. siłownie na wolnym powietrzu, ścieżki rowerowe, place zabaw i miejsca do uprawiania gier 
towarzyskich i sportowych. Parki wykazują w większości ogólną dostępność, tylko kilka zamykanych jest w godzinach nocnych.

Tab. 2

Udział procentowy parków w powierzchni wybranych miast Polski oraz powierzchnia przypadająca na 1 mieszkańca w latach 1996-2010

Percentage share of parks in the area of selected Polish cities and the area per capita in the years 1996-2010

\begin{tabular}{|c|c|c|c|c|c|c|c|c|}
\hline \multirow[t]{2}{*}{ Miasto } & \multicolumn{4}{|c|}{$\begin{array}{c}\text { \% udział parków } \\
\text { w powierzchni miasta }\end{array}$} & \multicolumn{4}{|c|}{ Powierzchnia w $\left(\mathrm{m}^{2}\right) / 1$ mieszk. } \\
\hline & 1996 & 2000 & 2006 & 2010 & 1996 & 2000 & 2006 & 2010 \\
\hline Białystok & 1,90 & 1,06 & 0,93 & 0,76 & 6,19 & 3,34 & 3,25 & 2,67 \\
\hline Bydgoszcz & 4,07 & 4,60 & 5,04 & 5,00 & 18,65 & 21,66 & 24,41 & 24,93 \\
\hline Częstochowa & 0,85 & 0,86 & 0,92 & 0,93 & 5,28 & 5,49 & 6,08 & 6,27 \\
\hline Gdańsk & 0,53 & 0,56 & 0,63 & 0,80 & 3,07 & 3,24 & 3,70 & 4,65 \\
\hline Gorzów Wlkp. & 1,45 & 1,63 & 1,61 & 1,61 & 8,97 & 10,04 & 11,05 & 11,06 \\
\hline Katowice & 1,62 & 3,20 & 3,15 & 4,03 & 7,70 & 16,11 & 16,56 & 21,72 \\
\hline Kielce & 1,45 & 1,54 & 0,57 & 0,57 & 7,47 & 7,94 & 3,02 & 3,08 \\
\hline Kraków & 0,91 & 0,97 & 1,21 & 1,22 & 4,14 & 4,32 & 5,40 & 5,40 \\
\hline Lublin & 1,09 & 1,09 & 3,47 & 1,29 & 4,67 & 4,60 & 14,84 & 5,58 \\
\hline Lódź & 2,04 & 2,04 & 2,10 & 1,98 & 7,42 & 7,59 & 8,16 & 7,94 \\
\hline Olsztyn & 0,71 & 0,76 & 0,76 & 0,82 & 3,86 & 4,04 & 3,95 & 4,26 \\
\hline Opole & 1,11 & 1,11 & 1,10 & 1,89 & 8,47 & 8,44 & 8,63 & 15,00 \\
\hline Poznań & 1,72 & 1,80 & 1,94 & 1,33 & 7,99 & 8,29 & 9,15 & 6,40 \\
\hline Radom & 0,52 & 0,59 & 0,62 & 0,62 & 2,49 & 2,83 & 3,04 & 3,08 \\
\hline Rzeszów & 1,28 & 1,28 & 1,01 & 0,63 & 4,47 & 4,48 & 4,38 & 4,25 \\
\hline Szczecin & 0,54 & 0,54 & 0,54 & 0,54 & 3,97 & 3,98 & 4,02 & 4,06 \\
\hline Toruń & 0,45 & 0,45 & 0,50 & 0,50 & 2,59 & 2,50 & 2,85 & 2,86 \\
\hline Warszawa & - & - & 1,71 & 1,79 & - & - & 5,22 & 5,40 \\
\hline Wrocław & 2,06 & 2,51 & 2,84 & 2,79 & 9,65 & 11,72 & 13,34 & 13,11 \\
\hline Średnia & 1,35 & 1,48 & 1,61 & 1,53 & 6,50 & 7,26 & 7,95 & 7,99 \\
\hline
\end{tabular}

\subsection{ZIELEŃCE, ZIELEŃ ULICZNA I TERENY ZIELENI OSIEDLOWEJ}

Udział poszczególnych kategorii terenów zieleni $\mathrm{w}$ miastach uwarunkowany jest czynnikami lokalnymi. Wpływ na to mają zarówno aspekty środowiskowe, jak i względy planistyczne czy architektoniczne. Duży udział zieleńców i terenów zieleni osiedlowej w Łodzi zawsze wyróżniał to miasto wśród innych ośrodków. Łódź z racji dużej powierzchni zajmowanej przez miasto posiada znaczną powierzchnię obszarów niezabudowanych pokrytych 
roślinnością w wyniku samozasiewów. W przypadku działek prywatnych tereny te często nie są pielęgnowane, miejscami zabiegi pielęgnacyjne ograniczają się do koszenia.

Duża gęstość sieci komunikacyjnej stwarza możliwości rozwoju zieleni przyulicznej. Ta kategoria należy do najbardziej zadbanych z punktu widzenia częstotliwości zabiegów pielęgnacyjnych. Problemem są zanieczyszczenia komunikacyjne mające negatywny wpływ na stan roślinności niskiej i wysokiej (Niedbała i in. 2010; Dusza-Dobek 2012; Szwalec, Mundała 2012). Problem ten pojawia się w ciągu całego roku, a w okresie zimowym dodatkowym czynnikiem degradującym jest zasolenie. Problem ten w śródmieściu Łodzi jest jednak znikomy. W przeprowadzonych badaniach gleb zieleni przyulicznej nie stwierdzono obecności znacznych ilości soli (Tołoczko i in. 2009).

Cechą charakterystyczną jest za to niewielki udział terenów zieleni ulicznej, najniższy spośród analizowanych miast (tab. 3). W ramach terenów zieleni osiedlowej ważnym elementem strukturalnym są ogrody działkowe. W strukturze miast stanowią one jedne z niewielu powierzchni wykazujących znaczenie produkcyjno-zaopatrzeniowe. W samej Łodzi obiektów Rodzinnych Ogrodów Działkowych jest około sto.

Opisywane kategorie terenów zieleni cechuje ogólnodostępność, choć wynika ona bardziej z potrzeb społecznych (mieszkaniowych, działalności gospodarczej itp.), niż chęci skorzystania $\mathrm{z}$ terenów zieleni jako obiektów rekreacyjnych, może z wyjątkiem terenów zieleni osiedlowej (zwłaszcza boisk i placów zabaw) wykorzystywanych przede wszystkim przez młodszych mieszkańców.

Tab. 3

Udział procentowy zieleńców, terenów zieleni ulicznej i osiedlowej w powierzchni wybranych miast Polski w latach 1996-2010*

Percentage share of squares, roadside vegetation and estate green areas in the area of selected Polish cities in the years 1996-2010

\begin{tabular}{|l|c|c|c|c|c|c|c|c|c|c|c|}
\hline \multirow{2}{*}{ Miasto } & \multicolumn{4}{|c|}{ Zieleńce } & \multicolumn{3}{c|}{ Zieleń uliczna } & \multicolumn{3}{c|}{ Tereny zieleni osiedlowej } \\
\cline { 2 - 14 } & 1996 & 2000 & 2006 & 2010 & 2000 & 2006 & 2010 & 1996 & 2000 & 2006 & 2010 \\
\hline 1 & 2 & 3 & 4 & 5 & 6 & 7 & 8 & 9 & 10 & 11 & 12 \\
\hline Białystok & 0,22 & 0,11 & 0,10 & 0,15 & 1,67 & 1,57 & 1,86 & 3,19 & 3,04 & 3,06 & 3,04 \\
\hline Bydgoszcz & 0,44 & 0,90 & 0,41 & 0,41 & 0,69 & 1,31 & 1,63 & 1,96 & 2,12 & 2,01 & 2,37 \\
\hline Czestochowa & 0,16 & 0,20 & 0,18 & 0,25 & 0,67 & 0,68 & 0,85 & 1,52 & 1,48 & 2,37 & 1,65 \\
\hline Gdańsk & 0,25 & 0,25 & 0,25 & 0,56 & 0,63 & 0,69 & 0,83 & 1,47 & 0,94 & 1,29 & 1,45 \\
\hline $\begin{array}{l}\text { Gorzów } \\
\text { Wlkp. }\end{array}$ & 1,56 & 1,56 & 1,41 & 1,41 & 0,35 & 0,52 & 0,54 & 2,07 & 2,09 & 1,03 & 1,07 \\
\hline Katowice & 0,25 & 0,26 & 0,31 & 0,30 & 1,04 & 1,46 & 0,30 & 2,72 & 2,09 & 3,35 & 2,08 \\
\hline Kielce & 0,05 & 0,06 & 0,06 & 0,09 & 1,15 & 1,28 & 1,28 & 1,78 & 3,08 & 2,78 & 2,25 \\
\hline Kraków & 0,57 & 0,69 & 0,52 & 0,90 & 1,21 & 1,40 & 1,86 & 1,98 & 2,12 & 2,24 & 2,86 \\
\hline Lublin & 0,66 & 0,66 & 0,70 & 0,69 & 1,56 & 1,58 & 1,60 & 2,82 & 2,80 & 3,87 & 3,92 \\
\hline
\end{tabular}


Tab. 3 (ciąg dalszy)

\begin{tabular}{|l|c|c|c|c|c|c|c|c|c|c|c|}
\hline \multicolumn{1}{|c|}{1} & 2 & 3 & 4 & 5 & 6 & 7 & 8 & 9 & 10 & 11 & 12 \\
\hline Lódź & $\mathbf{0 , 9 4}$ & $\mathbf{0 , 9 4}$ & $\mathbf{0 , 9 4}$ & $\mathbf{0 , 9 4}$ & $\mathbf{0 , 2 6}$ & $\mathbf{0 , 2 7}$ & $\mathbf{0 , 2 7}$ & $\mathbf{2 , 9 6}$ & $\mathbf{2 , 9 0}$ & $\mathbf{3 , 1 6}$ & $\mathbf{3 , 4 7}$ \\
\hline Olsztyn & 0,52 & 0,47 & 0,35 & 0,57 & 1,28 & 1,27 & 1,35 & 2,86 & 2,62 & 2,08 & 5,53 \\
\hline Opole & 0,02 & 0,03 & 0,03 & 0,05 & 0,90 & 0,93 & 2,24 & 2,13 & 1,02 & 1,61 & 1,87 \\
\hline Poznań & 0,32 & 0,30 & 0,28 & 0,34 & 1,32 & 1,13 & 1,36 & 2,12 & 2,04 & 2,03 & 2,41 \\
\hline Radom & 1,62 & 1,64 & 1,61 & 1,61 & 0,19 & 0,71 & 0,72 & 1,97 & 1,97 & 2,02 & 2,37 \\
\hline Rzeszów & 1,30 & 1,30 & 1,03 & 0,76 & 2,44 & 2,06 & 1,53 & 4,04 & 4,20 & 1,77 & 1,18 \\
\hline Szczecin & 0,18 & 0,18 & 0,16 & 0,16 & 0,41 & 0,71 & 0,67 & 0,59 & 0,80 & 0,71 & 0,82 \\
\hline Toruń & 0,38 & 0,40 & 0,41 & 0,41 & 0,73 & 0,79 & 1,00 & 2,50 & 2,35 & 1,72 & 2,00 \\
\hline Warszawa & - & - & 0,44 & 0,39 & - & 2,59 & 2,06 & - & - & 3,29 & 3,64 \\
\hline Wrocław & 0,62 & 0,28 & 0,75 & 0,44 & 1,27 & 1,66 & 1,73 & 1,28 & 1,59 & 1,49 & 1,64 \\
\hline Średnia & $\mathbf{0 , 5 6}$ & $\mathbf{0 , 5 7}$ & $\mathbf{0 , 5 2}$ & $\mathbf{0 , 5 6}$ & $\mathbf{0 , 9 9}$ & $\mathbf{1 , 1 9}$ & $\mathbf{1 , 2 5}$ & $\mathbf{2 , 2 2}$ & $\mathbf{2 , 1 8}$ & $\mathbf{2 , 2 0}$ & $\mathbf{2 , 4 0}$ \\
\hline
\end{tabular}

* - w Banku Danych Lokalnych brak danych dotyczących statystyki terenów zieleni ulicznej w Polsce dla roku 1996.

\subsection{CMENTARZE}

Cmentarze należą do wyjątkowych form zieleni miejskiej wykazujących odmienne funkcje i ograniczonych pod względem dostępności. Z uwagi na różnorodne znaczenie (społeczne, wychowawcze, estetyczne, dydaktyczne, krajobrazowe) stanowią jedne $\mathrm{z}$ najczęściej odwiedzanych obszarów zieleni. W przypadku dużych miast stanowią one istotny element krajobrazu kulturowego i są wyraźnie widoczne w strukturze, mimo niewielkiej sumarycznej powierzchni, nawet przy dużej liczbie obiektów. Udział cmentarzy w badanych ośrodkach wahał się w zakresie od 0,12\% (Radom) do 0,98\% (Poznań) powierzchni miasta w roku 2006. Średnia dla wszystkich analizowanych miast dla tego roku wyniosła $0,54 \%$, wartość dla Łodzi $0,77 \%$. Zmienność w roku 2010 osiągnęła zakres od 0,35\% (Gdańsk) do 0,96\% (Poznań), przy średniej 0,57\% powierzchni miasta. Łódź w okresie ostatniego pięciolecia nie zmieniła powierzchni cmentarzy $\mathrm{w}$ strukturze miasta. Biorąc pod uwagę względy jakościowe, pielęgnacja roślinności na terenach cmentarzy nie jest ograniczona W porównaniu $\mathrm{z}$ innymi formami zieleni, co wynika $\mathrm{z}$ zaangażowania osób odwiedzających, dla których względy estetyczne stanowią jeden z priorytetów fizjonomii tychże obiektów. Warta podkreślenia jest zwłaszcza funkcja kulturowa, choć ostatnimi laty cmentarze coraz bardziej zyskują funkcję rekreacyjną, czego najlepszym przykładem jest główny cmentarz miejski w Szczecinie (Czekiel-Świtalska 2010). 


\subsection{LASY}

Tereny lasów, poza funkcją rekreacyjną, ochronną, ekologiczną i edukacyjną spełniają także ważne funkcje krajobrazowe. Są one uzależnione w dużej mierze od stanu roślinności, która z racji licznych źródeł zanieczyszczeń może być i często jest odbierana negatywnie, zmniejszając estetykę i znaczenie lasów miejskich. Problem ten zauważano w badaniach na obszarach zalesionych w miastach (Andrzejewski 1975; Bach, Pawłowska 2007).

Mimo, iż obecnie lasy miejskie nie odgrywają większej roli w krajowym bilansie zasobów leśnych, warto zwrócić uwagę na ich znaczenie w kształtowaniu sieci terenów zieleni na obszarach miejskich i pełnione funkcje w krajobrazie, społeczne, ekologiczne itd. R. Jaszczak (2008) w swoich badaniach zauważa, że ogólna lesistość polskich miast na prawach powiatu waha się od $0,6 \%$ (Krosno) do 51,7\% (Sopot). Większość miast Polski charakteryzuje lesistość nie przekraczająca 10\% powierzchni (Opole, Wrocław, Radom). W przypadku większości dużych miast udział lasów waha się w przedziale 10-30\% (Łódź, Kielce, Bydgoszcz, Olsztyn, Poznań, Szczecin, Gdańsk, Toruń, Białystok, Lublin). Obszar Łodzi w przeszłości historycznej porastała Puszcza Łódzka, zapewniająca miastu i okolicznym osadom drewna będącego zasobem energetyczno-budowlanym. Śladem dawnych lasów są trzy kompleksy oraz pozostałości drzewostanów pierwotnych zachowane w łódzkich parkach. Ostatnimi czasy zauważalna jest jednak tendencja rozwoju obszarów zalesionych, poprzez zwiększanie ich areału i systematyczne nasadzenia. Nieco inaczej wygląda kwestia ogólnodostępnych lasów gminnych, których udział w powierzchni miast jest zdecydowanie mniejszy (tab. 4).

Największy udział lasów w ogólnej powierzchni miast mają Olsztyn i Szczecin. To drugie miasto, $z$ racji bardzo dużej powierzchni i stosunkowo małej liczby mieszkańców, posiada bardzo wysoki wskaźnik powierzchni leśnej przypadającej na 1 mieszkańca. Problemem jest ograniczona dostępność rekreacyjna terenów leśnych, gdyż znaczna ich część należy do Lasów Państwowych, przez co wykazują niski stopień zagospodarowania wynikający w niewielkiej ilości infrastruktury drogowej (dróg, ścieżek, duktów itp.) czy braku oświetlenia (Meyer 2011). Powoduje to kumulację ruchu turystycznego na mniejszej powierzchni, przez co normy chłonności terenów dostępnych są kilkunastokrotnie przekroczone. Podobna sytuacja ma miejsce na obszarach leśnych Łodzi. Dotyczy to zwłaszcza Lasu Łagiewnickiego, będącego jednym z największych (1 205 ha) miejskich kompleksów leśnych w Europie, posiadającego znaczenie komunalne i rekreacyjne oraz ochronne, z uwagi na istnienie w jego obrębie rezerwatu leśnego o pow. niemal 70 ha. 
Udział procentowy lasów gminnych w powierzchni wybranych miast Polski i powierzchnia $\mathrm{w}\left(\mathrm{m}^{2}\right)$ przypadająca na 1 mieszkańca w latach 2000-2010

Percentage share of communal forests in the area of selected Polish cities and the area in $\left(\mathrm{m}^{2}\right)$ per capita in the years 2000-2010

\begin{tabular}{|l|c|r|r|r|r|r|}
\hline \multirow{2}{*}{ Miasto } & \multicolumn{3}{|c|}{ Udział \% lasów } & \multicolumn{2}{c|}{ Powierzchnia w $\left(\mathrm{m}^{2}\right) / 1$ mieszk. } \\
\cline { 2 - 7 } & 2000 & 2006 & 2010 & 2000 & 2006 & 2010 \\
\hline Białystok & 2,16 & 1,76 & 2,10 & 6,79 & 6,17 & 7,32 \\
\hline Bydgoszcz & 1,01 & 0,83 & 0,89 & 4,74 & 4,03 & 4,45 \\
\hline Częstochowa & 0,12 & 0,20 & 0,21 & 0,76 & 1,32 & 1,39 \\
\hline Gdańsk & 3,68 & 3,94 & 3,99 & 21,15 & 23,14 & 23,12 \\
\hline Gorzów Wlkp. & 0,27 & 0,58 & 0,60 & 1,68 & 3,95 & 4,09 \\
\hline Katowice & 0,24 & 0,27 & 0,28 & 1,22 & 1,40 & 1,51 \\
\hline Kielce & 0,10 & 0,93 & 0,75 & 0,52 & 4,97 & 4,04 \\
\hline Kraków & 2,52 & 2,64 & 2,62 & 11,29 & 11,74 & 11,62 \\
\hline Lublin & 0,00 & 0,00 & 0,00 & 0,00 & 0,00 & 0,02 \\
\hline Lódź & $\mathbf{5 , 0 3}$ & $\mathbf{4 , 9 8}$ & $\mathbf{5 , 0 0}$ & $\mathbf{1 8 , 7 1}$ & $\mathbf{1 9 , 3 3}$ & $\mathbf{2 0 , 0 1}$ \\
\hline Olsztyn & 13,15 & 14,89 & 14,90 & 69,98 & 77,94 & 77,50 \\
\hline Opole & 0,11 & 0,14 & 0,14 & 0,86 & 1,10 & 1,14 \\
\hline Poznań & 7,87 & 8,06 & 7,88 & 36,29 & 38,12 & 37,99 \\
\hline Radom & 0,17 & 0,39 & 0,43 & 0,82 & 1,93 & 2,15 \\
\hline Rzeszów & 0,00 & 0,00 & 1,14 & 0,00 & 0,00 & 7,71 \\
\hline Szczecin & 6,84 & 8,22 & 8,23 & 50,78 & 61,59 & 62,18 \\
\hline Toruń & 3,75 & 4,07 & 4,07 & 21,03 & 23,29 & 23,52 \\
\hline Warszawa & - & 0,84 & 0,36 & - & 2,57 & 1,09 \\
\hline Wrocław & 2,56 & 2,73 & 2,92 & 11,96 & 12,79 & 13,68 \\
\hline Średnia & $\mathbf{2 , 7 6}$ & $\mathbf{2 , 9 2}$ & $\mathbf{2 , 9 7}$ & $\mathbf{1 4 , 3 7}$ & $\mathbf{1 5 , 5 5}$ & $\mathbf{1 6 , 0 3}$ \\
\hline
\end{tabular}

\subsection{TERENY ZIELENI MIEJSKIEJ OGÓLEM}

Koncepcje założeniowe i rozwojowe terenów zieleni miejskiej są bardzo zróżnicowane i uwarunkowane wielorakimi względami. Większość miast posiada charakterystyczne układy zieleni, np. pierścieniowy (Poznań, Warszawa, Wrocław, Kielce), kompleksowy (Gdańsk, Olsztyn), promienisto-koncentryczny (Kraków), czy rozproszony (Łódź) (Matczak 1994; Urbański i in. 2009; Świercz 2011). Zachowanie układu, bądź zaplanowanie jego ewolucji, stanowi poważne wyzwanie dla urbanistów i architektów. Ważnym aspektem jest uwzględnienie udziału terenów zieleni w przestrzeni miejskiej ogółem, jak i zwrócenie uwagi na potencjalnych użytkowników poszczególnych ich kategorii. E. Czekiel-Świtalska (2010) wykazała, iż Łódź jest miastem oferującym swoim mieszkańcom jedną $\mathrm{z}$ największych $\mathrm{w}$ Polsce powierzchni publicznych terenów zieleni. Średnio na 1 mieszkańca przypada $24,1 \mathrm{~m}^{2}$, przy czym większość miast w kraju 
może zaoferować swym mieszkańcom około 10-15 $\mathrm{m}^{2}$ terenów zieleni, a nawet mniej. W odniesieniu do historii, w Łodzi już po II wojnie światowej udział terenów zieleni przypadających na 1 mieszkańca wynosił $31,6 \mathrm{~m}^{2}$, a powierzchnia ta systematycznie rosła do ponad $40 \mathrm{~m}^{2} \mathrm{w}$ latach 70 . i aż $66,5 \mathrm{~m}^{2}$ na początku lat 90. XX wieku. Zmiany ustrojowe i gospodarcze przyczyniły się jednak do ograniczenia powierzchni wielu terenów zieleni (zwłaszcza lasów i powierzchni zajmowanych przez zieleń osiedlową ), co miało miejsce nie tylko na terenie Łodzi (Urbański i in. 2009). Warto dodać także, że wzrost powierzchni zieleni miejskiej przypadającej na 1 mieszkańca obserwowany w ostatnich latach jest pozorny i wynika głównie ze stale zmniejszającej się liczby ludności miasta.

W statystyce udziału ogólnej powierzchni terenów zieleni w powierzchni wybranych miast, Łódź zajęła w 2010 r. trzecie miejsce za Olsztynem i Poznaniem (tę samą pozycję utrzymuje od ok. 2000 r.) (tab. 5). Najmniejszy udział wśród analizowanych miast wykazały Częstochowa, Kielce, Gorzów Wlkp. i Rzeszów. W przeliczeniu na statystycznego mieszkańca największa powierzchnia terenów zieleni występuje w Olsztynie, Szczecinie i Poznaniu. Łódź w tym zestawieniu uzyskała siódmy wynik (szósty w 2000 r.), nie odbiegając znacznie od średniej w całym analizowanym okresie. Pojawiły się jednak problemy związane z dostępnością, wynikającą ze słabego zagospodarowania niektórych kategorii terenów zieleni. Najgorzej w tym względzie mają mieszkańcy stolicy, Częstochowy, Kielc, Radomia i Białegostoku.

Łódź posiada ponadto w strukturze terenów zieleni obiekty o wyjątkowym znaczeniu dydaktycznym, wychowawczym, ochronnym, spełniających różnorakie funkcje. Są to ogrody: botaniczny i zoologiczny. Koncepcje założeniowe ogrodu botanicznego sięgają okresu międzywojennego. Pierwsza lokalizacja z roku 1929 nie przetrwała próby czasu. Obecny ogród, zaprojektowany zaraz po II wojnie światowej zajmuje powierzchnię 67 ha i jest obiektem o wyjątkowym znaczeniu edukacyjnym oraz estetycznym (http://www.botaniczny.lodz.pl/ historia-ogrodu.html). Łódzki ogród zoologiczny powstał w roku 1938. Jego obecna powierzchnia wynosi 16,4 ha, co daje mu dziesiątą pozycję wśród 15 podobnych obiektów zlokalizowanych w Polsce. Cechą wyróżniającą jest duże bogactwo florystyczne zwłaszcza drzewostanów. Na terenie ogrodu występuje aż 356 gatunków drzew (http://www.zoo.lodz.pl). Z punktu widzenia znaczenia w przestrzeni oba obiekty mają zasięg co najmniej regionalny.

Wspomniany wcześniej problem braku spójnej koncepcji zagospodarowania i wykorzystania terenów zieleni w miastach, często traktowanych jako potencjalny zasób terenów inwestycyjnych, dotyczy niektórych ośrodków nawet obecnie, np. w Szczecinie i Poznaniu (Mierzejewska 2004; Meyer 2011). O ile informacje o terenach zieleni zawarte są w studiach uwarunkowań i zagospodarowania przestrzennego miast, o tyle często trudno znaleźć informacje dotyczące przyszłości tych terenów, poza wskazaniem strategii zrównoważonego rozwoju. Inaczej wygląda to np. w Toruniu (Jaroszewska-Brudnicka, Brudnicki 2011), 
czy Łodzi, dla których istnieją koncepcje rozwoju wybranych terenów zieleni, a nawet pojedynczych obiektów. Takie podejście znacznie usprawnia racjonalne gospodarowanie terenami zielonymi, $\mathrm{w}$ pełnej symbiozie $\mathrm{z}$ pozostałą przestrzenią miejską. Opracowany dla Łodzi System Przyrodniczy Miasta, będący znaną od kilku dziesięcioleci koncepcją planistyczną (Szulczewska, Kaliszuk 2005), charakteryzuje pierścieniowe założenia konstrukcji terenów zieleni w mieście z uwzględnieniem ograniczeń rozwoju (Studium... 2009).

Tab. 5

Sumaryczny udział terenów zieleni w powierzchni wybranych miast Polski oraz powierzchnia terenów zieleni przypadająca na 1 mieszkańca w latach 1996-2010

Total percentage share of green areas in the area of selected Polish cities and the area of green areas per capita in the years 1996-2010

\begin{tabular}{|l|c|r|r|r|r|r|r|r|}
\hline \multirow{3}{*}{ Miasto } & \multicolumn{3}{|c|}{$\begin{array}{c}\text { Udział \% terenów zieleni } \\
\text { w powierzchni miasta }\end{array}$} & \multicolumn{3}{c|}{ Powierzchnia w $\left(\mathrm{m}^{2}\right)$} \\
& 1996 & 2000 & 2006 & 2010 & 1996 & 2000 & 2006 & 2010 \\
\cline { 2 - 10 } & 5,31 & 8,05 & 8,29 & 8,78 & 17,28 & 25,28 & 29,01 & 30,62 \\
\hline Białystok & 6,47 & 9,31 & 10,17 & 10,86 & 29,66 & 43,84 & 39,53 & 54,18 \\
\hline Bydgoszcz & 2,53 & 3,33 & 4,65 & 4,23 & 15,73 & 21,24 & 30,63 & 28,56 \\
\hline Częstochowa & 2,25 & 6,07 & 6,97 & 7,99 & 12,98 & 34,83 & 41,00 & 46,29 \\
\hline Gdańsk & 5,08 & 5,91 & 5,62 & 5,65 & 31,42 & 36,38 & 38,52 & 38,73 \\
\hline Gorzów Wlkp. & 4,59 & 6,83 & 8,94 & 7,46 & 21,88 & 34,39 & 47,01 & 40,21 \\
\hline Katowice & 3,28 & 5,94 & 6,02 & 5,33 & 16,92 & 30,52 & 31,99 & 28,81 \\
\hline Kielce & 3,45 & 7,52 & 8,44 & 9,88 & 15,77 & 33,63 & 37,54 & 43,82 \\
\hline Kraków & 4,56 & 6,10 & 10,11 & 8,02 & 19,58 & 25,80 & 43,26 & 34,66 \\
\hline Lublin & $\mathbf{5 , 9 4}$ & $\mathbf{1 1 , 1 7}$ & $\mathbf{1 2 , 2 1}$ & $\mathbf{1 2 , 4 3}$ & $\mathbf{2 1 , 5 9}$ & $\mathbf{4 1 , 5 6}$ & $\mathbf{4 7 , 4 1}$ & $\mathbf{4 9 , 7 6}$ \\
\hline Lódź & 4,10 & 18,27 & 20,26 & 24,09 & 22,26 & 97,22 & 106,04 & 125,26 \\
\hline Olsztyn & 3,25 & 3,17 & 4,25 & 6,66 & 24,91 & 24,16 & 33,30 & 52,84 \\
\hline Opole & 4,17 & 13,32 & 14,43 & 14,28 & 19,29 & 61,46 & 68,25 & 68,87 \\
\hline Poznań & 4,10 & 4,55 & 5,47 & 6,20 & 19,70 & 21,99 & 26,98 & 31,01 \\
\hline Radom & 6,63 & 9,23 & 6,47 & 5,66 & 23,04 & 32,22 & 27,91 & 38,15 \\
\hline Rzeszów & 1,31 & 8,78 & 10,94 & 11,04 & 9,72 & 65,12 & 82,00 & 83,41 \\
\hline Szczecin & 3,32 & 7,68 & 8,23 & 8,72 & 19,34 & 43,04 & 47,05 & 50,35 \\
\hline Toruń & - & - & 9,58 & 8,96 & - & - & 29,26 & 27,04 \\
\hline Warszawa & 3,96 & 8,22 & 9,80 & 10,01 & 18,57 & 38,36 & 45,98 & 46,96 \\
\hline Wrocław & $\mathbf{4 , 1 3}$ & $\mathbf{7 , 9 7}$ & $\mathbf{8 , 9 9}$ & $\mathbf{9 , 2 8}$ & $\mathbf{1 9 , 9 8}$ & $\mathbf{3 9 , 5 0}$ & $\mathbf{4 4 , 8 8}$ & $\mathbf{4 8 , 4 0}$ \\
\hline Średnia & & & & & & & & \\
\hline
\end{tabular}

W 2011 r. Łódź jako miasto była bazą przestrzenną międzynarodowego projektu pt. „Usługi ekosystemów jako warunek zrównoważonego rozwoju miast” (Łódź Europejska... 2011), finansowanego ze środków Deutsche Bundesstiftung Umwelt i Narodowego Funduszu Ochrony Środowiska i Gospodarki Wodnej. Projekt miał na celu potrzebę popularyzacji efektywnych praktyk w zarządzaniu przestrzenią miejską. Zwrócono dzięki niemu uwagę na kluczowe 
zagadnienia związane z gospodarką terenami zielonymi. Uwzględniając możliwość realizacji projektu, przy założeniu pełnej akceptacji wytycznych i koncepcji, z pewnością ma on szansę zwrócić uwagę na Łódź jako jedno z najbardziej zielonych miast w Polsce.

Okres od akcesji Polski do Unii Europejskiej spowodował wzrost zainteresowania terenami zieleni miejskiej w aspekcie pozyskiwania środków na ich rewitalizację i rewaloryzację. W ramach środków Wojewódzkiego Funduszu Ochrony Środowiska i Gospodarki Wodnej w samym tylko 2013 r. dokonano wsparcia finansowego projektów dotyczących rewitalizacji jednego z najstarszych parków Łodzi - Źródliska I (kwota dotacji to $3 \mathrm{mln}$ zł, które dodatkowo powiększono o 1,2 mln ze środków urzędu miasta), edukacji ekologicznej na terenie Lasu Łagiewnickiego i ogrodu zoologicznego, renowacji stawów w dwóch parkach miejskich (3-go Maja i Sielanka) oraz pielęgnacji starodrzewi (http://bip.zzm.lodz.pl/dofinansowanie.html). Poprawia się także stan infrastruktury, głównie wyposażenie w ławki, kosze na odpadki oraz oświetlenie, którego brak szczególnie ograniczał dostępność niektórych obiektów.

\section{WNIOSKI}

1. Zmiany jakie zaszły w ciągu ostatnich kilkunastu latach ujawniają tendencję ograniczania powierzchni terenów zieleni, wynikającą z licznych inwestycji, głównie drogowych. Co prawda w Łodzi proces ten nie pociąga jeszcze za sobą negatywnych skutków, zarówno z punktu widzenia zagospodarowania przestrzennego, jak i względów zdrowotnych czy estetycznych, choć pojawia się aspekt degradacji drzewostanów i roślinności niższej. Wzrost udziału terenów zieleni przypadającej na 1 mieszkańca Łodzi jest wynikiem spadku liczby ludności miasta.

2. Udział niektórych rodzajów terenów zieleni (lasy, zieleńce, zieleń osiedlowa) stawia Łódź w czołówce dużych ośrodków miejskich w Polsce. Problemem jest niski stan zagospodarowania obiektów i ograniczona dostępność (zwłaszcza lasów i po części parków). Negatywnym tego skutkiem jest kumulacja liczby użytkowników utrudniająca korzystanie z niektórych obiektów.

3. Znaczenie terenów zieleni w mieście jest bardzo różnorodne, tak pod względem zasięgu oddziaływania, jak i funkcjonalności. Pojedyncze obiekty skupiają wiele funkcji. Bardzo ważnym jest znaczenie ekologiczne, które wpływa na zmianę wizerunku Łodzi jako miasta przemysłowego, zwłaszcza ludności je zamieszkującej, na co wpływa duża powierzchnia terenów zieleni przypadająca na 1 mieszkańca.

4. Mimo wskazanych problemów, Łódź na tle analizowanych ośrodków miejskich posiada znaczny udział ogólnej powierzchni terenów zieleni. Można zatem stwierdzić, zgodnie z informacjami podawanymi przez innych badaczy, iż należy ona do jednych z najbardziej ,zielonych” miast w Polsce. 


\section{LITERATURA}

Andrzejewski R., 1975, Problemy ekologiczne ksztaltowania środowiska $w$ mieście, „Wiadomości Ekologiczne”, 21, 3, s. 175-186.

Bach A., Pawłowska B., 2007, Wpływ zanieczyszczenia środowiska na stan roślinności drzewiastej w Krakowie, „Czasopismo Techniczne”, 10 - Architektura, 5A, s. 114116.

Bazan-Krzywoszańska A., 2005, Polityka przestrzenna a tereny zielone na przykładzie miasta Zielona Góra, Teka Komisji Architektury, Urbanistyki i Studiów Krajobrazowych, I/2005, s. 119-127.

Czekiel-Świtalska E., 2010, Rola zieleni $w$ mieście na przykładzie centrum Szczecina, „Przestrzeń i Forma”, 13, s. 165-182.

Czerwieniec M., Lewińska J., 2000, Zieleń w mieście, Wydawnictwo IPGiK, Kraków, ss. 82.

Dusza-Dobek A., 2012, Badania geochemiczne gleb w wybranych parkach Warszawy, „Biuletyn Państwowego Instytutu Geologicznego”, 450, s. 35-46.

Jaroszewska-Brudnicka R., Brudnicki R., 2011, Obszary przyrodniczo cenne jako element przestrzeni publicznej miasta, Studia i Materiały CEPL w Rogowie, 13, 3 (28), s. $213-218$.

Jaszczak R., 2008, Las i gospodarka leśna w zasięgu oddziatywania miast $w$ Polsce, Studia i Materiały CEPL w Rogowie, 3 (19), s. 152-171.

Łódź Europejska Zielona Stolica do 2020 roku, 2011, Raport projektu w ramach XIV Akademii Letniej pt. Wyzwania Zrównoważonego Rozwoju w Polsce, Łódź, ss. 166. http://www.sendzimir.org.pl.

Matczak A., 1994, Tereny zielone w strukturze Łodzi, „Kronika Miasta Łodzi”, 1/94, s. 69-80.

Matczak A., 1995, Wykorzystanie wypoczynkowe terenów zielonych miasta Łodzi, „Acta Universitatis Lodziensis, Folia Geographica”, 19, s. 83-100.

Meyer B., 2011, Tereny leśne Szczecina jako obszar aktywności turystycznej i rekreacyjnej mieszkańców, Studia i Materiały CEPL w Rogowie, 13, 3 (28), s. 207-212.

Mierzejewska L., 2004, The natural environment in the sustainable development of towns: the example of Poznań, Dela, 21, s. 593-602.

Mowszowicz J. (red.), 1962, Parki Łodzi, Wydawnictwo ŁTN, Łódź, ss. 244.

Niedbała M., Smolińska B., Król K., 2010, Zanieczyszczenia gleb miejskich miasta Łodzi wybranymi pierwiastkami śladowymi, „Chemia Spożywcza i Biotechnologia”, 74, 1081, s. 29-38.

Pancewicz A., 2007, Rola elementów środowiska przyrodniczego w procesie odnowy zdegradowanego krajobrazu miejskiego, „Czasopismo Techniczne”, 10 - Architektura, 5A, s. 64-66.

Przesmycka N., 2005, Przeobrażenia historycznych terenów zielonych Lublina do 1939 roku, Teka Komisji Architektury, Urbanistyki i Studiów Krajobrazowych, I/2005, s. $157-167$.

Słodczyk J., 2001, Przestrzeń miasta i jej przeobrażenia, „Studia i monografie”, 298, s. 243-248. 
Studium uwarunkowań i kierunków zagospodarowania przestrzennego miasta Łodzi założenia rozwoju, 2009, Miejska Pracownia Urbanistyczna, Łódź, ss. 74. http://www.mpu.lodz.pl.

Sutkowska E., 2006, Współczesny ksztatt i znaczenie zieleni miejskiej jako zielonej przestrzeni publicznej w strukturze miasta - przestrzeń dla kreacji, Teka Komisji Architektury, Urbanistyki i Studiów Krajobrazowych, II/2006, s. 184-192.

Szulczewska B., Kaliszuk E., 2005, Koncepcja systemu przyrodniczego miasta: geneza, ewolucja i znaczenie praktyczne, Teka Komisji Architektury, Urbanistyki i Studiów Krajobrazowych, I/2005, s. 7-24.

Szwalec A., Mundała P., 2012, Zawartość Cd, Pb, Zn i Cu w glebach wybranych parków Krakowa, „Ochrona Środowiska i Zasobów Naturalnych”, 53, s. 63-72.

Świercz A., 2011, Zieleń miejska w systemie przyrodniczym Kielc - ksztaltowanie, wskaźniki, „Problemy Ekologii Krajobrazu”, 39, s. 173-184.

Tołoczko W., Niewiadomski A., Trawczyńska A., 2009, Influence of salinity on the sorptive features in soils of Lodz city centre, "Ecological Chemistry and Engineering”, ser. A, 16, 4, s. 465-474.

Urbański P., Krzyżaniak M., Rydzewska A., 2009, Zieleń Poznania i innych miast w Polsce, „Nauka-Przyroda-Technologie”, 3, 1, s. 1-10.

\section{ŹRÓDLA ELEKTRONICZNE}

http://bip.zzm.lodz.pl/dofinansowanie.html [online], dostęp z dn. 09.12.2013.

http://www.botaniczny.lodz.pl/historia-ogrodu.html [online], dostęp z dn. 09.12.2013.

http://www.zoo.lodz.pl [online], dostęp z dn. 09.12.2013.

http://www.sendzimir.org.pl/sites/default/files/Raport\%20z\%20projektu\%20Lodz\%20E

uropejska\%20Zielona\%20Stolica\%20do\%202020\%20roku.pdf. [online], dostęp z dn.

15.11.2013.

http://www.mpu.lodz.pl/page/bip.php?str=276. [online], dostęp z dn. 10.04.2012.

\section{SUMMARY}

The article compares the role and structure of green areas in Łódź to other big cities in Poland. It describes how the share of green areas in town space has changed during the last 15 years with the reference to historical background. The main part of the work is a comparative analysis of the space of green areas in selected major cities. The author considers main functions of green areas, attaching the importance of landscape, ecological and social function. Transformations of particular categories of green areas were indicated. Problems of care and availability of green areas were noted. Results have confirmed that Łódź is one of the greenest big cities in Poland and some categories of green areas play a special role in urban ecology and spatial development.

Keywords: green areas, Łódź, spatial economy, urban landscape 